\title{
PROGNOSTIC FACTORS ON THE POSITIVITY FOR METASTASES OF THE AXILLARY LYMPH NODES FROM PRIMARY BREAST CANCER
}

\author{
Borislav Kondov ${ }^{1}$, Goran Kondov ${ }^{1}$, Zoran Spirovski ${ }^{1}$, Zvonko Milenkovikj ${ }^{2}$, \\ Risto Colanceski ${ }^{1}$, Gordana Petrusevska ${ }^{3}$, Meri Pesevska ${ }^{4}$ \\ ${ }^{1}$ University Clinic for Thoracic and Vascular Surgery - Medical Faculty Skopje, R. Macedonia \\ ${ }^{2}$ University Clinic for Infective Disease and Febrile Conditions - Medical Faculty Skopje, R. Macedonia \\ ${ }^{3}$ Institute for Pathology - Medical Faculty Skopje, R. Macedonia \\ ${ }^{4}$ University Clinic for Oncology and Radiotherapy- Medical Faculty Skopje R. Macedonia
}

Corresponding Authors: Borislav Kondov, University Clinic for Thoracic and Vascular Surgery, Skopje, Majka Tereza 17, 1000 Skopje, R Macedonia, tel.: 072539 003, e-mail: b_kondov@yahoo.com

\section{ABSTRACT}

Aim: The aim of the study was to identify the impact of T stage, the presence of estrogen, progesterone, HER2neu receptors and the values of the Ki67 on the positivity for metastases of the axillary lymph nodes, from primary breast cancer.

Material and methods: 290 surgically treated patients for breast cancer were included in the study. All cases have been analyzed by standard histological analysis including microscopic analysis on standard H\&E staining. For determining the molecular receptors - HER2neu, ER, PR, p53 and Ki67, immunostaining by PT LINK immunoperoxidase has been done.

Results: Patients age was ranged between $18-90$ years, average of $57.6 \pm 11.9$. The mean size of the primary tumor in the surgically treated patient was $30.27+18.3 \mathrm{~mm}$. On dissection from the axillary pits 8 to 39 lymph nodes were taken out, an average of $13.81 \pm 5.56$. Metastases have been found in 1 to 23 lymph nodes, an average $3.14 \pm 4.71$. In $59 \%$ of the patients there have been found metastases in the axillary lymph nodes. The univariate regression analysis showed that the location, size of tumor, differentiation of the tumor, stage, the value of the Ki67 and presence of lymphovascular invasion influence on the positivity of the axillary lymph nodes. The presence of the estrogen receptors, progesterone receptors and HER2neu receptors showed that they do not have influence on the positivity for metastatic deposits in axillary lymph nodes. The multivariate model and the logistic regression analysis as independent significant factors or predictors of positivity of the axillary lymph nodes are influenced by the tumor size and the positive lymphovascular invasion.

Conclusion: Our study showed that the involving of the axillary lymph nodes is mainly influenced by the size of the tumor and the presence of lymphovascular invasion in the tumor. Ki67 determined proliferative index in the univariate analysis points the important influence of positivity in the axillary lymph nodes, but not in the multivariate regressive analysis.

Key words: breast cancer, axillar status, tumor size, T stage, estrogen receptors, progesterone receptors, HER2neu receptors, Ki67, lymphovascular invasion

\section{INTRODUCTION}

Involvement of axillary lymph nodes with metastatic disease from primary breast cancer is the most significant prognostic factor of the disease. Some factors are well known to influence the prognosis of the disease and early appearance of the local and distant relapse.
The axillar status (involvement of lymph nodes in axilla with metastatic diseases from primary breast cancer) together with the size of the primary breast tumor are the main factors that determine the stage of breast cancer, but also predict the prognosis of the breast cancer disease (1). Up to now all information about the axillar status were taken from the examinations of the axillar lymph nodes that we take out 
with the axillar lymphadenectomy. This is part of the surgical treatment of patients with breast cancer - radical mastectomy or breast conserving surgery followed with axillar lymphadenectomy.

Introducing the procedure - detection of the sentinel node and biopsy is minimally invasive procedure that determines the first drainage lymph node in the axillar pit (2). The examination of this lymph node at the same surgical intervention gives us information about the status of this lymph node, but also gives us information about other lymph nodes in axilla.

Knowing the status of the axilla is very important, for the planning of the further therapeutic procedure.

\section{AIM}

To analyze which factors have an influence on the positivity of the axillar lymph nodes, with point to tumor size, persistence of estrogen, progesterone and Her 2new receptors on tumor cell surface, Ki67, at our patients.

\section{MATERIAL AND METHODS}

290 surgically treated patients for breast cancer that have a complete history for all parameters were included in the study. All the cases have been analyzed with standard histological analysis including macroscopic and microscopic analysis on standard H\&E staining. For determining the molecular receptors immunostaining with PT LINK immunoperoxidase has been done for HER2neu, ER, PR, p53 and Ki67.

We performed the statistical analyze with the statistical program Statistica 7.

\section{RESULTS}

Patient's age ranged between $18-90$ years, average of 57.6. The mean size of the primary tumor in the surgically treated patient was $30.27 \pm 18.3 \mathrm{~mm}$. On dissection, 8 to 39 lymph nodes were taken from the axillary pits, an average of 13.81. Metastases have been found in 1 to 23 lymph nodes, an average 3.14 . In $59 \%$ of the patients metastases in the axillary lymph nodes have been found.

The univariate regression analysis showed that the location, size of tumor, differentiation of the tumor, stage, the value of the Ki67 and presence of lymphovascular invasion influence on the positivity of the axillary lymph nodes. The presence of the estrogen receptors, progesterone receptors and
HER2neu receptors showed that they do not have influence on the positivity for metastatic deposits in the axillary lymph nodes. The multivariate model and the logistic regression analysis as independent significant factors or predictors of positivity of the axillary lymph nodes are influenced by the tumor size and the positive lymphovascular invasion. (Table 1.)

\section{DISCUSSION}

Axillar lymphadenectomy gives us parameters for axillar status, but at same time it is a therapeutic procedure. On the other hand, axillar lymphadenectomy was followed with many unlike features and complications as sensation in the arm, reduction of the arm mobility and lymphedema (3). Using the thesis of Fisher and Veronesi, that breast cancer is the systemic disease at the moment of the diagnosis, so it needs to be treated as systemic disease with drugs that work in the whole body (chemotherapeutic, antihormonal therapy, immunotherapy) $(4,5)$. So, the axillar status is the first diagnostic tool and in many instances, especially if it is not involved with metastatic disease, which is in $40-70 \%$, it is not necessary to do an axillar lymphadenectomy. This situation will be more reliable with introducing mammographic screening, with detecting much smaller tumors and without involved lymph nodes in the axillar pit (6).

The prediction of the axillar status can be used to predict the whole axillar status, to predict the sentinel node and to predict the non-sentinel node status if the sentinel node is positive. In the last case it is possible to use prediction, and not to do axillar lymphadenectomy in case when the sentinel lymph node is positive, because in $40-50 \%$ cases the other lymph nodes is negative $(7,8,9,10)$.

Many authors use some standard methods for prediction of the axillar status, as clinical examination, mammography, ultrasonography, and also introduce new methods like ultrasound guide biopsy, CT, NMRI, Pet-CT, SPETCT, contrast examinations. In many cases they have detected enlarged lymph nodes, but it is impossible to guarantee that all this is metastatic changed (low sensitivity) $(11,12,13$, 14). With the use of these methods it is possible only to lower the rate of false negative results (15).

The introduction of the SLND detection, especially if both types of detection are used, as vital blue due (methylene blue) and the radioisotope Technetium with colloid particles (radiocolloid) at the end of the last century give us very successful tool for the SLND detection, which histological examination gives us a successfully status of SLND, but also the status of the whole axilla. The successful rate 
of SLND detection is $98 \%(74-99 \%)$, and the false negative rate is less than $5 \%(0-19 \%)(16,17,18$, $19,20)$. The false negative rate can be lower using the extirpated sentinel lymph node in the investigation and not only the histological examination of the frozen sections, but also the use of the immunohistochemical analyses with cytokeratin, or the use of OSNA (analyzing the amplification of the RNA copies of CA19)(16, 17, 21, 22, 23).

In literature there are many investigations for determination of the factors that can predict the positivity of axilla, SLND and NSLND if SLND is positive. Those factors can be divided in few categories:

- Epidemiological (age, race, side, localization)

- Clinical (palpable tumor, palpable axillar lymph nodes, location of the tumor)

- Pathological (histology of tumor, differentiation of cells, neovascularization of the tumor, vascular and lymphovascular invasion, extensive intraductal component, persistence of the receptors on the surface of the cells - estrogen, progesterone, Her-2 new, persistence of $\mathrm{p} 53$ proteins, persistence of factor of proliferation Ki67. By knowing these parameters it is possible to determine the subtype of the breast cancer.

- Biochemical (CEA, CA 15-3)

- Genetic (BRCA 1, BRCA2, VEGFC, MIB1, CCR7, CXCR4 ) (24-60).

Some of these investigations can be provided to the material taken from the tumor before the surgical intervention with "core" biopsy, which is very important for planning further therapeutic steps (42).

As first prediction the axillar status gives us the possibility to introduce SLND biopsy as minimally invasive surgery, especially in the early stages, but also in some cases with well-defined tumors which are in the early stage, it is possible not to do lymphadenectomy. If we know the axillar status before the beginning of the treatment we can:

- plan to perform the SLND investigation at the early stages of breast cancer (T1 or T2 with clinically negative axilla), and if this node is negative not to further conduct the axillar lymphadenectomy. In the literature it is referred that SLND was indicated at $60-70 \%$ of patients with breast cancer, and at $60-70 \%$ of them will be with negative SLND, and it will be not necessary to perform the lymphadenectomy. This is the reality especially in regions where mammographic screening is done.
- plan not to perform SLND or ALND in rare cases, in different tumors, older patients, with very low chances for metastases in the lymph nodes.

- plan to use other therapeutic opportunities as systematic therapy or radiotherapy.

Many of the factors that were examined as predictors for axillar status are very well known. Also, there are known pathophysiological mechanisms of their action, and it is very well known how is their action to the biology of the tumor and how they work to spared the disease in the body. So, estrogen receptors are on the surface of the cell. The connection of the estrogen and the estrogen receptors activate many processes in the cell and favor the raising and the dividing the cells. So, estrogen favors the rising of the tumor. Giving the drugs that blockade the estrogen receptors or drugs that blockade the synthesis of the estrogen will stop the rise of the tumor. The same situation is with the persistence of Her-2 neu receptors. HER 2 is a membrane tyrosine kinase and oncogene that is overexpressed and gene amplified in about $20 \%$ of breast cancers. When activated it provides the cell with potent proliferative and anti-apoptosis signals and it is the major driver of the tumor development and the progression of the breast cancer. The over expression will activate many pathways in the cell, so the cells will raise and divide uncontrolled, so the tumor will raise and will not be under control. Giving the target drug - monoclonal antibody - Trastuzumab (Herceptin) will block these receptors, and the tumor will be under control. Moreover, giving chemotherapeutics which interact with all the cells that divide fast; the tumor will be under control. Ki67 is a factor that shows the proliferative activity of the tumor cells. Ki67 is in correlation with the $\mathrm{S}$ phase of the cells and mitotic activity. Normal breast cell has a proliferative activity of 3\% (3\% of the cells are in dividing stage). A bigger activity of $20 \%$ shows the aggressive tumor with bad prognosis and shorter survival $(61,62,63)$.

Many investigators analyze many factors, how they enable, or in combination can predict the status of the axillar lymph nodes, the SLND status and in recent time the NSLND status. Postaci, Jiao, Jaime Jans, Ugras, Gangi, Pijnappel, Sawaki, Brenin, Chung, Chadha, Tan, Gajdos, Qiu, Ashturkar, Wu, Tseng, Ko, Li, Ngo, Yoo, Danko, Cabioglu, Capdet, Susini, Wasuthit are part of authors that in the last decade investigated which factors influence the positivity of the axillar lymph node or the positivity of the sentinel node. They investigate all the factors that can be investigated like epidemiological, clinical, histo- 
pathological, genetic, and molecular. Mainly, from all those studies the dominant factors that can influence the positivity of the axillar nodes are: the size of the tumor, location, histology, grade of differentiation, lymphovascular invasion. But, also in many investigations other factors that can influence the positivity of the axillar lymph nodes are referred: age, persistence of estrogen, progesterone and Her 2 neu receptors on the surface of the cells, subtype of breast cancer, the values of Ki67, multifocality, EIC and other. In only few studies VEGFC, MIB1, CEA, CA 15-3, CCR7, CXCR4 and others were referred (24-47).

In the studies of Jiao, Pijnappel, Sawaki, Gangi, Qiu one of the essential factors that predict the axillar involvement is the persistence of the hormonal receptors and Her 2 receptors on the tumor cell, moreover, it is well defined that Luminal and Her enriched the tumors lymph nodes are more often were involved in the metastatic disease. On the other hand, triple negative tumors rarely have involvement in the lymph nodes with metastatic disease, however, this type shows early distant metastasis and worse prognosis. But many others studies show that the persistence of the hormone receptors, Her 2 receptors on the surface of the tumor cells has no influence on the involvement of the axillar lymph nodes with metastases. So it is interesting which are the factors that influence the fact that the same factor in one study is the main factor, and in other study it is not an important one $(25,28,29,30,36)$.

In our study the univariate regression analysis showed that the location, size of tumor, differentiation of the tumor, stage, the value of the Ki67 and the presence of the lymphovascular invasion influence the positivity of the axillary lymph nodes. The presence of the estrogen receptors, progesterone receptors and HER2 neu receptors showed that they do not have influence on the positivity for the metastatic deposits in the axillary lymph nodes. The multivariate model and the logistic regression analysis as independent significant factors or predictors of positivity of the axillary lymph nodes are influenced by the tumor size and the positive lymphovascular invasion.

The predicting of the NSLND positivity is important, and it is very current in the last years, because according to some investigations $30-40 \%$ of Z011 in the axillar pit are only sentinel node positive, so in these patients it is not necessary to do axillar lymphadenectomy (48).

For this reasons there were defined many nomograms for predicting status, where different factors from three to nine were incorporated, with various combinations. So now it is actual not to do the axillar lymphadenectomy also in patients with positive 1 or 2 sentinel lymph nodes in which the nomogram assists the prediction of the further progress of the disease in other lymph nodes in the axillar pit. These patients must be treated with systemic therapy and locally radiotherapy (48).

Factors that are included in many of the nomograms are: tumor size, tumor differentiations, lymphovascular invasion, number of positive SLND, number of negative SLND, size of metastasis in SLND, type of SLND detection, type of histological examination of SLND, number of CK 19 determined with OSNA, Ki 67 and others (49-60).

Most popular nomograms are:

- MSKCC that involves: size of tumor, differentiation of tumor-G, number of positive SLND, number of negative SLND, type of detection SLND, LVI, multimodality and positivity for estrogen receptors. This is the most frequently used, and one of the best for prediction.

- Stanford that involves: size of tumor, size of metastases in SLND, and LVI.

- Tenon that involves: size of tumor, ratio between positive and negative SLND, size of metastases in SLND.

- Bolster that involves: size of tumor, LVI, size of SLND metastases.

- Cambridge that involves: differentiation of tumor-G, ratio between SLND+ and SLND, size of SLND metastases.

- MDA that involves: size of SLND metastases, size of tumor, LVI, number of extracted SLND.

- Mayo that involves: age, size of SLND metastases, number of SLND positive, number of SLND negative, size of Tumor.

- Ljubljana that involves: size of metastases in SLND, number of SLND negative, number of SLND positive, size of tumor, LVI, ultrasound findings.

The investigation of the factors that involve NSLD are done by: Metini, Xiang, Miao, Nadem, Van der Hoven, Yao lung Kuo, Cordero, Pepeles, Gur, Gserini, Fredman, Gullen, Van la Para, Wiliams (49-60). Some of them test some nomograms in their patients and suggest which is the best for prediction. But no one can predict with $100 \%$ safety, status of axilla, or SLND in all patients, so it is necessary as minimum to do the detection and the biopsy of the sentinel node, which is further histology examined. By detecting the status of the sentinel node we can safely predict the status of other lymph nodes in axilla. 


\section{CONCLUSION}

Our study showed that the involving of the axillary lymph nodes is mainly influenced from the size of the tumor and the presence of lymphovascular invasion in the tumor. Ki67 determined the proliferative index in the univariate analysis and points out the important influence on the positivity in the axillary lymph nodes but not in the multivariate regressive analysis.

Table1. Characteristics of the primary breast cancer in our patients

\begin{tabular}{|c|c|c|c|c|}
\hline Variable & $\begin{array}{c}\text { Axilla positive } \\
\left(\mathrm{no}_{0}=171\right)\end{array}$ & $\begin{array}{c}\text { Axilla negative } \\
(\mathrm{no}=119)\end{array}$ & $\begin{array}{c}\text { Total } \\
(\mathrm{no}=290)\end{array}$ & p \\
\hline \multicolumn{5}{|c|}{ Tumor size } \\
\hline Tis & $3(1,75 \%)$ & $10(8,40 \%)$ & $13(4,48 \%)$ & \\
\hline T1a & $22(12,86 \%)$ & $15(12,60 \%)$ & $37(12,76 \%)$ & \\
\hline T1b & $5(2,92 \%)$ & $11(9,24 \%)$ & $16(5,51 \%)$ & \\
\hline T1c & $21(12,28 \%)$ & $27(22,68 \%)$ & $48(16,55 \%)$ & \\
\hline $\mathrm{T} 2$ & $93(54,38 \%)$ & $50(42,02 \%)$ & $143(49,31 \%)$ & \\
\hline T3 & $13(7,60 \%)$ & $2(1,68 \%)$ & $15(5,17 \%)$ & \\
\hline T4 & $14(8,19 \%)$ & $4(3,36 \%)$ & $18(6,19 \%)$ & $1,0 \mathrm{~ns}$ \\
\hline \multicolumn{5}{|l|}{ Location } \\
\hline Central & $39(22,8 \%)$ & $22(18,49 \%)$ & $61(21,03 \%)$ & \\
\hline Inner & $19(11,11 \%)$ & $18(15,12 \%)$ & $37(12,06 \%)$ & \\
\hline Lateral & $113(66,08 \%)$ & $79(66,39 \%)$ & $192(66,91 \%)$ & $0,79 \mathrm{~ns}$ \\
\hline \multicolumn{5}{|l|}{ Histology } \\
\hline Ductal & $141(82,46 \%)$ & $96(80,67 \%)$ & $237(81,44 \%)$ & \\
\hline Lobular & $18(10,53 \%)$ & $9(7,56 \%)$ & $27(9,31 \%)$ & \\
\hline Other & $12(7,02 \%)$ & $14(11,76 \%)$ & $26(8,97 \%)$ & $0,86 \mathrm{~ns}$ \\
\hline \multicolumn{5}{|c|}{ Nuclear grade } \\
\hline 1 & $3(1,75 \%)$ & $13(10,92 \%)$ & $16(5,52 \%)$ & \\
\hline 2 & $115(67,25 \%)$ & $87(73,11 \%)$ & $202(69,65 \%)$ & \\
\hline 3 & $53(30,99 \%)$ & $19(15,96 \%)$ & $72(24,48 \%)$ & $0,99 \mathrm{~ns}$ \\
\hline \multicolumn{5}{|c|}{ Estrogen receptors } \\
\hline Positive & $130(76,02 \%)$ & $85(71,43 \%)$ & $215(74,14 \%)$ & \\
\hline Negative & $41(23,98 \%)$ & $34(28,57 \%)$ & $75(25,86 \%)$ & $0,53 \mathrm{~ns}$ \\
\hline \multicolumn{5}{|c|}{ Progesteron receptors } \\
\hline Positive & $139(81,29 \%)$ & $87(73,11 \%)$ & $226(77,93 \%)$ & \\
\hline Negative & $32(18,71 \%)$ & $32(18,71 \%)$ & $64(22,07 \%)$ & $0,75 \mathrm{~ns}$ \\
\hline \multicolumn{5}{|c|}{ Her 2 new receptors } \\
\hline Positive & $52(30,41 \%)$ & $38(31,93 \%)$ & $90(31,03 \%)$ & \\
\hline Negative & $119(69,59 \%)$ & $81(68,07 \%)$ & $200(68,97 \%)$ & $0,37 \mathrm{~ns}$ \\
\hline \multicolumn{5}{|l|}{ P53 } \\
\hline Positive & $88(51,46 \%)$ & $43(36,13 \%)$ & $131(45,18 \%)$ & \\
\hline Negative & $83(48,54 \%)$ & $76(63,86 \%)$ & $159(54,82 \%)$ & $0,92 \mathrm{~ns}$ \\
\hline \multicolumn{5}{|l|}{ LVI } \\
\hline Positive & $99(57,89 \%)$ & $18(15,13 \%)$ & $117(40,34 \%)$ & \\
\hline Negative & $72(42,10 \%)$ & $101(84,87 \%)$ & $173(39,65 \%)$ & $1,0 \mathrm{~ns}$ \\
\hline \multicolumn{5}{|l|}{ Ki67 } \\
\hline$<20$ & $58(33,92 \%)$ & $68(57,14 \%)$ & $126(43,20 \%)$ & \\
\hline$>20$ & $113(66,08 \%)$ & $51(42,86 \%)$ & $164(56,80 \%)$ & $0,99 \mathrm{~ns}$ \\
\hline \multicolumn{5}{|l|}{ Stage } \\
\hline $\mathbf{0}$ & & & $3(1,03 \%)$ & \\
\hline IA & & & $43(14,83 \%)$ & \\
\hline IB & & & $9(3,10 \%)$ & \\
\hline IIA & & & $83(28,62 \%)$ & \\
\hline IIB & & & $126(43,45 \%)$ & \\
\hline IIIA & & & $43(14,83 \%)$ & \\
\hline IIIB & & & $15(5,17 \%)$ & \\
\hline IIIC & & & $34(11,72)$ & \\
\hline
\end{tabular}




\section{REFERENCES}

1. Carter CL,Allen C, Henson DE. Relation of tumor size, lymph node status, and survival in 24,740 breast cancer cases. Cancer. 1989;63:181-187.

2. Giuliano A. E., Kirgan D. M., Guenther J. M., Morton D. L. Lymphatic mapping and sentinel lymphadenectomy for breast cancer. Annals of Surgery. 1994;220(3):391-401.

3. Maunsell E, Brisson J \& Deshenes L. Arm problems and psychological distress after surgery for breast cancer. Canadian Journal of Surgery 1993 Aug, 36(4) 315-20.

4. Fisher B, Jeong JH, Anderson S, et al. Twentyfive-year follow-up of a randomized trial comparing radical mastectomy, total mastectomy and total mastectomy followed by irradiation. $\mathrm{N}$ Engl J Med.2002;347(8):567-575.

5. Veronesi U, Saccozzi R, Del Vecchio M, et al. Comparing radical mastectomy with quadrantectomy, axillary dissection, and radiotherapy in patients with small cancer of the breast. N Engl J Med.1981;305(1):6-11.

6. Cady B, Stone MD, Schuler JG, Thakur R, Wanner MA \& Lavin PT 1996 The new era in breast cancer: invasion, size, and nodal involvement dramatically decreasing as a result of mammographic screening. Archives of Surgery 131 301-308.

7. Barth A, Craig PH, Silverstein MJ. Predictors of axillary lymph node metastases in patients with T1 breast carcinoma. Cancer. 1997;79:1918-22.

8. Tan YY, Wu CT, Fan YG, et al. Primary tumor characteristics predict sentinel lymph node macrometastasis in breast cancer. Breast J. 2005; 11:338-43.

9. Ravdin PM, De Laurentiis M, Vendely T, Clark GM. Prediction of axillary lymph node status in breast cancer patients by use of prognostic indicators. J Natl Cancer Inst. 1994;86:1771-75.

10. Hwang RF, Krishnamurthy S, Hunt KK, et al. Clinicopathologic factors predicting involvement of nonsentinel axillary nodes in women with breast cancer. Ann Surg Oncol. 2003;10:248-54.

11. Patani NR, Dwek MV, Douek M.Predictors of axillary lymph node metastasis in breast cancer: a systematic review.Eur J Surg Oncol. 2007 May;33(4):409-19.

12. Ahmed M, Purushotham AD, Douek M. Novel techniques for sentinel lymph node biopsy in breast cancer: a systematic review.Lancet Oncol. 2014 Jul;15(8):e351-62.

13. W. Byon, E. Kim, J. Kwon, BJ.Song, C. Park. FDG-PET, MRI and USG in the assessment of axillary lymph node metastases in breast cancerThe Breast 24S1 (2015) S67.

14. Hwang $\mathrm{SO}^{1}$, Lee SW, Kim HJ, Kim WW, Park HY, Jung JH. The Comparative Study of Ultrasonography, Contrast-Enhanced MRI, and (18) F-FDG PET/CT for Detecting Axillary Lymph Node Metastasis in T1 Breast Cancer.J Breast Cancer. 2013 Sep;16(3):315-21.

15. Hyun SJ, Kim EK, Yoon JH, Moon HJ, Kim MJ. Adding MRI to ultrasound and ultrasound-guided fine-needle aspiration reduces the false-negative rate of axillary lymph node metastasis diagnosis in breast cancer patients.Clin Radiol. 2015 Jul;70(7):716-22. doi: 10.1016/j. crad.2015.03.004.

16. Giuliano AE, Han SH. Local and regional control in breast cancer: role of sentinel node biopsy. Adv Surg. 2011;45:101-16.

17. Mamounas ET. Optimal Management of the Axilla: A Look at the Evidence. Adv Surg. 2016 Sep;50(1):29-40. doi: 10.1016/j. yasu.2016.03.003.

18. Moncayo VM, Aarsvold JN, Grant SF, Bartley SC, Alazraki NP. Status of sentinel lymph node for breast cancer.Semin Nucl Med. 2013 Jul;43(4):281-93. doi: 10.1053/j.semnuclmed.2013.02.004.

19. Gherghe M, Bordea C, Blidaru A. Sentinel lymph node biopsy (SLNB) vs. axillary lymph node dissection (ALND) in the current surgical treatment of early stage breast cancer. J Med Life. 2015 Apr-Jun;8(2):176-80.

20. Zervoudis S, Iatrakis G, Tomara E, Bothou A, Papadopoulos G, Tsakiris G. Main controversies in breast cancer.World J Clin Oncol. 2014 Aug 10;5(3):359-73. doi: 10.5306/wjco.v5.i3.359

21. Guillén-Paredes MP, Carrasco-González L, Cháves-Benito A, Campillo-Soto A, Carrillo A, Aguayo-Albasini JL. One-step nucleic acid amplification (OSNA) assay for sentinel lymph node metastases as an alternative to conventional postoperative histology in breast cancer: A cost-benefit analysis.Cir Esp. 2011 Aug-Sep;89(7):456-62. doi: 10.1016/j. ciresp.2011.04.013

22. Takamoto K, Shimazu K, Naoi Y, Shimomura A, Shimoda M, Kagara N, Kim SJ, Tamaki Y, Noguchi S. One-Step Nucleic Acid Amplification 
Assay for Detection of Axillary Lymph Node Metastases in Breast Cancer Patients Treated with Neoadjuvant Chemotherapy. Ann Surg Oncol. 2016 Jan;23(1):78-86. doi: 10.1245/s10434015-4693-y.

23. Jimbo K, Kinoshita T, Suzuki J, Asaga S, Hojo T, Yoshida M, Tsuda H. Sentinel and nonsentinel lymph node assessment using a combination of one-step nucleic acid amplification and conventional histological examination. Breast. 2013 Dec;22(6):1194-9. doi: 10.1016/j. breast.2013.08.003

24. Postac1 H, Zengel B, Yararbaş U, Uslu A, Eliyatkın N, Akpınar G, Cengiz F, Durusoy R-Sentinel lymph node biopsy in breast cancer: predictors of axillary and non-sentinel lymph node involvement. Balkan Med J. 2013 Dec;30(4):41521. doi: 10.5152/balkanmedj.2013.9591.

25. Jiao D, Qiao J, Lu Z, Li L, Zhang H, Liu H, Cui $\mathrm{S}$, Liu Z. Analysis of predictive factors affecting sentinel lymph node status in early breast cancer patients. Zhonghua Zhong Liu Za Zhi. 2014 Mar;36(3):198-201.

26. Jaime Jans B, Nicolás Escudero M, Dahiana Pulgar B, Francisco Acevedo C, César Sánchez $\mathrm{R}$, Camus AM-Clinicopathologic subtypes and compromise of lymph nodes in patients with breast cancer. Ecancermedicalscience. $2014 \mathrm{Jul}$ 23;8:448. doi: 10.3332/ecancer.2014.448. eCollection 2014.

27. Ugras S, Stempel M, Patil S, Morrow M. Estrogen receptor, progesterone receptor, and HER2 status predict lymphovascular invasion and lymph node involvement. Ann Surg Oncol. 2014 Nov;21(12):3780-6. doi: 10.1245/s10434014-3851-y.

28. Gangi A, Mirocha J, Leong T, Giuliano AE. Triple-negative breast cancer is not associated with increased likelihood of nodal metastases. Ann Surg Oncol. 2014 Dec;21(13):4098-103. doi: 10.1245/s10434-014-3989-7.

29. Pijnappel EN, Bhoo-Pathy N, Suniza J, See MH, Tan GH, Yip CH, Hartman M, Taib NA, Verkooijen HM.- Prediction of lymph node involvement in patients with breast tumors measuring $3-5 \mathrm{~cm}$ in a middle-income setting: the role of CancerMath. World J Surg. 2014 Dec;38(12):3133-7. doi: 10.1007/s00268-014-2752-3.

30. Sawaki M, Idota A, Ichikawa M, Gondo N, Horio A, Kondo N, Hattori M, Fujita T, Yatabe Y, Iwata H. - Impact of intrinsic subtype on predicting axillary lymph node metastasis in breast cancer. Oncol Lett. 2014 Oct;8(4):1707-1712.
31. Brenin DR, Manasseh DM, El-Tamer M, Troxel A, Schnabel F, Ditkoff BA, Kinne D. Factors correlating with lymph node metastases in patients with T1 breast cancer.Ann Surg Oncol. 2001 Jun;8(5):432-7.

32. Chung MJ, Lee JH, Kim SH, Suh YJ, Choi HJ. Simple Prediction Model of Axillary Lymph Node Positivity After Analyzing Molecular and Clinical Factors in Early Breast Cancer. Medicine (Baltimore). 2016 May;95(20):e3689. doi: 10.1097/MD.0000000000003689.

33. Chadha M, Chabon AB, Friedmann P, Vikram B. Predictors of axillary lymph node metastases in patients with $\mathrm{T} 1$ breast cancer. A multivariate analysis. Cancer. 1994 Jan 15;73(2):350-3.

34. Tan LG, Tan YY, Heng D, Chan MY Predictors of axillary lymph node metastases in women with early breast cancer in Singapore.Singapore Med J. 2005 Dec;46(12):693-7.

35. Gajdos C, Tartter PI, Bleiweiss IJ. Lymphatic invasion, tumor size, and age are independent predictors of axillary lymph node metastases in women with T1 breast cancers.Ann Surg. 1999 Nov;230(5):692-6

36. Qiu PF, Liu JJ, Wang YS, Yang GR, Liu YB, Sun $\mathrm{X}$, Wang CJ, Zhang ZP. Risk factors for sentinel lymph node metastasis and validation study of the MSKCC nomogram inbreast cancer patients. Jpn J Clin Oncol. 2012 Nov;42(11):1002-7

37. Ashturkar $\mathrm{AV}^{1}$, Pathak GS, Deshmukh SD, Pandave HT. Factors predicting the axillary lymph node metastasis in breast cancer: is axillary node clearance indicated in every breast cancer patient?: factors predicting the axillary lymphnode metastases in breast cancer.Indian J Surg. 2011 Oct;73(5):331-5.

38. Wu SG, He ZY, Ren HY, Yang LC, Sun JY, Li FY, Guo L, Lin HX. Use of CEA and CA15-3 to Predict Axillary Lymph Node Metastasis in Patients with Breast Cancer. J Cancer. 2016 Jan 1;7(1):37-41. doi: 10.7150/jca.13090. eCollection 2016

39. Tseng HS, Chen LS, Kuo SJ, Chen ST, Wang YF, Chen DR. Tumor characteristics of breast cancer in predicting axillary lymph node metastasis. Med Sci Monit. 2014 Jul 7;20:1155-61.

40. Ko BS, Lim WS, Kim HJ, Yu JH, Lee JW, Kwan SB, Lee YM, Son BH, Gong GY, Ahn SH.-Risk factor for axillary lymph node metastases in microinvasive breast cancer.Ann Surg Oncol. 2012 Jan;19(1):212-6. 
41. Ngô C, Mouttet D, De Rycke Y, Reyal F, Fourchotte V, Hugonnet F, Falcou MC, Bidard FC, Vincent-Salomon A, Fourquet A, Alran S. Validation over time of a nomogram including HER2 status to predict the sentinel node positivity in early breast carcinoma.Eur J Surg Oncol. 2012 Dec;38(12):1211-7

42. Yoo SH, Park IA, Chung YR, Kim H, Lee K, Noh DY, Im SA, Han W, Moon HG, Lee $\mathrm{KH}$, Ryu HS. A histomorphologic predictive model for axillary lymph node metastasis in preoperative breastcancer core needle biopsy according to intrinsic subtypes. Hum Pathol. 2015 Feb; 46(2):246-54. doi: 10.1016/j. humpath.2014.10.017.

43. Danko ME, Bennett KM, Zhai J, Marks JR, Olson JA Jr. Improved staging in node-positive breast cancer patients using lymph node ratio: results in 1,788 patients with long-term follow-up. J Am Coll Surg. 2010 May;210(5):797-805.e1, 805-7. doi: 10.1016/j.jamcollsurg.2010.02.045

44. Cabioglu N, Yazici MS, Arun B, Broglio KR, Hortobagyi GN, Price JE, Sahin A. CCR7 and CXCR4 as novel biomarkers predicting axillary lymph node metastasis in T1 breast cancer. Clin Cancer Res. 2005 Aug 15;11(16):5686-93

45. Capdet J, Martel P, Charitansky H, Lim YK, Ferron G, Battle L, Landier A, Mery E, Zerdoub $\mathrm{S}$, Roche H, Querleu D. Factors predicting the sentinel node metastases in T1 breast cancer tumor: an analysis of 1416 cases. Eur J Surg Oncol. 2009 Dec;35(12):1245-9. doi: 10.1016/j. ejso.2009.06.002.

46. Susini T, Nori J, Olivieri S, Molino C, Marini G, Bianchi S, Vezzosi V, Livi L, Mascalchi M, Scarselli G. Predicting the status of axillary lymph nodes in breast cancer: a multiparameter approach including axillary ultrasound scanning. Breast. 2009 Apr;18(2):103-8.

47. Wasuthit Y, Kongdan Y, Suvikapakornkul R, Lertsithichai P, Chirappapha P. Predictive factors of axillary lymph node metastasis in breast cancer.J Med Assoc Thai. 2011 Jan;94(1):65-70.

48. Giuliano AE, McCall L, Beitsch P, Whitworth PW, Blumencranz P, Leitch AM, Saha S, Hunt KK, Morrow M, Ballman K. Locoregional recurrence after sentinel lymph node dissection with or without axillary dissection in patients with sentinel lymph node metastases: the American College of Surgeons Oncology GroupZ0011 randomized trial.Ann Surg. 2010 Sep;252(3):426-32;
49. Meattini I, Saieva C, Bertocci S, Francolini G, Zei G, De Luca Cardillo C, Scotti V, Greto D, Bonomo P, Orzalesi L, Bianchi S, Livi L. Predictive factors for additional non-sentinel lymph node involvement in breast cancer patients with one positive sentinel node.Tumori. 2015 JanFeb; 101(1):78-83.

50. Nadeem RM, Gudur LD, Saidan ZA. An independent assessment of the 7 nomograms for predicting the probability of additional axillary nodal metastases after positive sentinel lymph node biopsy in a cohort of British patients with breastcancer.Clin Breast Cancer. 2014 Aug;14(4):272-9

51. van den Hoven I, Kuijt G, Roumen R, Voogd A, Steyerberg EW, Vergouwe Y. A head to head comparison of nine tools predicting non-sentinel lymph node status in sentinel node positive breast cancer women.J Surg Oncol. 2015 Aug;112(2):133-8.

52. van den Hoven I, van Klaveren D, Voogd AC, Vergouwe Y, Tjan-Heijnen V, Roumen RM. A Dutch Prediction Tool to Assess the Risk of Additional Axillary Non-Sentinel Lymph Node Involvement in Sentinel Node-Positive Breast Cancer Patients.Clin Breast Cancer. 2016 Apr;16(2):123-30.

53. Kuo YL, Chen WC, Yao WJ, Cheng L, Hsu HP, Lai HW, Kuo SJ, Chen DR, Chang TW. Validation of Memorial Sloan-Kettering Cancer Center nomogram for prediction of non-sentinel lymph node metastasis in sentinel lymph node positive breast cancer patients an international comparison.Int J Surg. 2013;11(7):538-43

54. Cordero JM, Bernet L, Cano R, Bustamante M, Vila R, Ballester B, González PJ. Study of the sentinel node in breast cancer using lymphoscintigraphy and a fast method for cytokeratin. Rev Esp Med Nucl. 2004 Jan-Feb;23(1):9-14

55. Gur AS, Unal B, Johnson R, Ahrendt G, Bonaventura M, Gordon P, Soran A. Predictive probability of four different breast cancer nomograms for nonsentinel axillary lymph node metastasis in positive sentinel node biopsy.J Am Coll Surg. 2009 Feb;208(2):229-35

56. Gur AS, Unal B, Ozbek U, Ozmen V, Aydogan F, Gokgoz S, Gulluoglu BM, Aksaz E, Ozbas S, Baskan S, Koyuncu A, Soran A; Turkish Federation of Breast Disease Associations Protocol MF08-01 investigators.- Validation of breast cancer nomograms for predicting the non-sentinel lymph node metastases after a positive 
sentinel lymph node biopsy in a multi-center study. Eur J Surg Oncol. 2010 Jan;36(1):30-5.

57. Cserni G, Bori R, Maráz R, Leidenius MH, Meretoja TJ, Heikkila PS, Regitnig P, Luschin-Ebengreuth G, Zgajnar J, Perhavec A, Gazic B, Lázár G, Takács T, Vörös A, Audisio RA. Multi-institutional comparison of non-sentinel lymph node predictive tools in breast cancer patients with high predicted risk of further axillary metastasis. Pathol Oncol Res. 2013 Jan;19(1):95-101

58. Cserni G, Boross G, Maráz R, Leidenius MH, Meretoja TJ, Heikkila PS, Regitnig P, Luschin-Ebengreuth G, Zgajnar J, Perhavec A, Gazic B, Lázár G, Takács T, Vörös A, Audisio RA. Multicentre validation of different predictive tools of non-sentinel lymph node involvement in breast cancer.Surg Oncol. 2012 Jun;21(2):59-65.

59. Freedman GM, Fowble BL, Li T, Hwang ES, Schechter N, Devarajan K, Anderson PR, Sigurdson ER, Goldstein LJ, Bleicher RJ. Risk of positive nonsentinel nodes in women with 1-2 positive sentinel nodes related to age and molecular subtype approximated by receptor status. Breast J. 2014 Jul-Aug;20(4):358-63

60. Gülben K, Berberoğlu U, Aydoğan O, Kınaş $\mathrm{V}$. Subtype is a predictive factor of nonsentinel lymph node involvement in sentinel node-positive breast cancer patients.J Breast Cancer. 2014 Dec;17(4):370-5.

61. Cecilia Williams and Chin-Yo Lin Oestrogen receptors in breast cancer: basic mechanisms and clinical implications; Ecancermedicalscience. 2013; 7: 370.

62. Carolina Gutierrez, M.D. and Rachel Schiff, Ph.D. HER 2: Biology, Detection, and Clinical Implications; Arch Pathol Lab Med. 2011 Jan; 135(1): 55-62.

63. P J van Diest, E van der Wall, and J P A Baak. Prognostic value of proliferation in invasive breast cancer: a review. J Clin Pathol. 2004 Jul; 57(7): 675-681.

\section{Резиме}

\section{ПРОГНОСТИЧКИ ФАКТОРИ НА ПОЗИТИВИТЕТОТ ЗА МЕТАСТАЗИ НА АКСИЛАРНИТЕ ЛИМФНИ ЈАЗЛИ КАЈ ПРИМАРЕН КАРЦИНОМ НА ДОЈКА}

\section{Борислав Кондов ${ }^{1}$, Горан Кондов ${ }^{1}$, Зоран Спировски ${ }^{1}$, Звонко Миленковиќ ${ }^{2}$, Ристо Чоланчески ${ }^{1}$, Гордана Петрушевска ${ }^{3}$, Мери Пешевска ${ }^{4}$}

${ }^{1}$ Универзитетска клиника за торакална и васкуларна хирургија

- Медицински факултет Скопје, Р. Македонија

2 Универзитетска клиника за инфективни болести и фебрилни состојби

- Медицински факултет Скопје, Р. Македонија

${ }^{3}$ Институт за патологија

- Медицински факултет Скопје, Р. Македонија

${ }^{4}$ Универзитетска клиника за онкологија и радиотерапија

- Медицински факултет во Скопје, Р. Македонија.

\section{Апстракт}

Цел: Целта на студијата беше да се одреди влијанието на Т-стадиумот, присуството на естроген, прогестерон, HER2neu рецептори и вредностите на Ki67 на позитивитетот за метастази во аксиларните лимфни жлезди кај примарен карцином на дојка.

Материјал и методи: Во студијата беа вклучени 290 хируршки третирани пациенти поради карцином на дојка. Сите случаи беа анализирани со стандардните хистолошки анализи, вклучувајќ́ микроскопска анализа со стандардно H\&E-боење. За одредување на молекуларните рецептори - HER2neu, ER, PR, p53 и Ki67, беше применета обработка со PT LINK-имунопероксидаза.

Резултати: Пациентите беа на возраст од 18 до 90 години, просечно 57,56+11,9. Средната големина

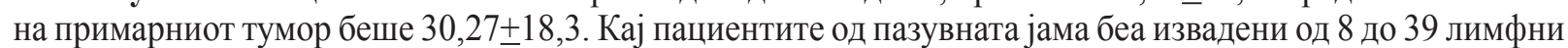


јазли, просечно 13,815,56. Зафатени со метастаски депозит беа од 1 до 23 јазли, просечно 3,14_4,71. Позитивност на аксиларни лимфни јазли е детектирана кај 59\%. Со униваријантна регресиска анализа беа издвоени следниве фактори, кои влијаат на позитивност на аксила: локација, големина на туморот, диференцираност на туморот, стадиум, вредност на Ки67 и лимфоваскуларна инвазија. Присуството на естрогени рецептори, прогестеронски рецептори и HER2neu рецептори покажа дека тие немаат влијание на позитивитетот за метастатските депозити во аксиларните лимфни јазли. Мултиваријантниот модел на логистичка регресиска анализа, како независни сигнификантни фактори, односно предиктори за позитивноста на лимфните јазли во пазувната јама, ги потврди големината на тумурот и позитивната лимфоваскуларна инвазија на тумурот.

Заклучок: Од иследувањата во нашата серија се утврди дека на позитивитетот на аксиларната јама влијание има големината на туморот и позитивната лимфоваскуларна инвазија на туморот. Факторот Ki67, кој ја презентира способноста за делба, биолошката агресивност на туморот, во униваријантната анализа укажува на значајно влијание за позитивитетот на аксиларните лимфни јазли.

Клучни зборови: малигном на дојка, аксиларен статус, големина на туморот, Т-стадиум, естрогени рецептори, прогестеронски рецептори, херцептински рецептори, Ки67, лимфоваскуларна инвазија 